Reducing prices of old products Maintaining research

Supporting semi-public institutions

Holding open the door of opportunity

Business men have been soft-minded, that is, not mentally weak, but geared to a cowardly attitude as to their own place in society. The clergy, landed gentlemen, and scholars have helped to hold them down. Schools of business in this country may be expected to dispel some of the established inferiority complex, and perhaps the existing reaction against the New Deal may help develop a long-needed philosophy. Certainly the growth of a professional attitude on the part of business executives in the middle ranks, such as accountants, advertising managers, and personnel managers, will help to create an esprit de corps now lacking and a social status not yet accepted. We may have to wait for more intellectual maturity, however, before there can be widespread differentiation between the chief executive of a business and the chief brigand of a robber band. To be sure, the contribution of captains of industry and business statesmen in the present war may have had some temporary influence in the direction of the slow-dawning enlightenment.
N. S. B. GRAS, Harvard University.

\title{
The Judgment of the Historian Upon American Business
}

"What is the judgment of American historians today upon American business?" This question was discussed by Dr. Stanley Pargellis, an historian and the librarian of the Newberry Library. at a recent dinner of the Newcomen Society at Chicago. The address, which was published by the American Branch of that Society and appeared in abbreviated form in the Railway Agc for February 26, 1944, has proved of great interest to business men. Dr. Pargellis has kindly consented to mail the address to any readers of the Bulletin who may desire a copy. Send your request to him at the Newberry Library, Chicago. 